\title{
NAFKAH ISTERI BEKERJA: SATU TINJAUAN DI DAERAH PASIR MAS KELANTAN
}

\author{
Nabilah Abdullah* \\ Wan Zulkifli Wan Hassan**
}

\begin{abstract}
In Muslim marriage system, it is a duty of a husband to give maintenance to his family, and a wife is responsible to household matters. But in modern society, some wives are also going out to work and to help in financial support to the family. This study discusses the concept of working wives in Islamic perspective by analyzing Muslim jurist's views on maintenance and the ethics of the working wives. To get a real picture on this, a field study employing questionnaire methods have been done, where 150 working wives in the District of Pasir Mas, Kelantan have been selected randomly as the samples. The data collected are analyzed and presented in table. The study finds that the majority husbands of the working wives are still carrying out their duty of providing subsistence to their wives and the majority of the working wives have generously support their husbands in their family financial aspects.
\end{abstract}

Keywords: maintenance, working wife, family law, husband

* Post Graduate Candidate at Academy of Islamic Studies, University of Malaya.

** Lecturer at Centre For General Studies, National University of Malaysia. 


\section{PENGENALAN}

Kajian ini bertujuan untuk mengetahui sejauhmanakah masyarakat di daerah Pasir Mas, Kelantan melaksanakan tanggunjawab nafkah isteri yang bekerja. Penulisan ini dimulakan dengan menghuraikan hukum wanita atau isteri bekerja di luar rumah mengikut perspektif Islam. Diikuti selepas itu dengan perbincangan mengenai sejauhmana nafkah wajib dilaksanakan oleh suami jika isterinya bekerja sedangkan pendapatan usami sudah cukup untuk menyara hidup mereka. Pandangan dan idea ulama dahulu dan semasa akan diketengahkan dan dianalisis. Kajian lapangan telah dilakukan di Daerah Pasir Mas, Kelantan ini bertujuan untuk meneliti, sejauhmana perlaksanaan nafkah terhadap isteri bekerja diterimapakai dalam masyarakat Islam.

\section{HUKUM ISTERI BEKERJA}

Perbincangan berkenaan dengan hukum isteri bekerja dapat dilihat dari sudut hukum wanita bekerja di luar rumah. Berhubung dengan masalah ini, terdapat dua pandangan dalam kalangan ulama. Pertama; pandangan ini dipelopori oleh majoritit ulama terutama ulama kontemporeri. Ini kerana mereka berpandukan kepada beberapa hujah dan dalil yang menguatkan pandangan mereka. Di antaranya adalah sebagaimana berikut:

i-Firman Allah S.W.T. yang bermaksud:

"Maka Tuhan mereka memperkenankan permohonannya(denganberfirman): "Sesungguhnya Aku tidak mensia-siakan amalan orang-orang yang beramal di antara maku yang terdiri dari kalangan lelaki dan wanita (kerana) sebahagian kamu adalah keturunan dari sebahagian yang lain”.

\section{Surah Āli ‘Imrān (3): 195}

Berpandukan ayat di atas, isteri termasuk dalam kalangan kaum wanita yang mempunyai sifat-sifat kewanitaan sebagaimana wanita-wanita lain. Wanita juga seperti kaum lelaki yang boleh berfikir, bekerja dan bertindak mengikut kemahuannya kerana mereka tergolong di kalangan manusia. Di samping itu juga, Allah 
S.W.T. telah menjelaskan bahawa fungsi kaum wanita adalah untuk memenuhi keperluan hidup kaum lelaki. Mereka saling memerlukan di antara satu sama lain. ${ }^{1}$

Selain itu, tabiat semulajadi yang ada pada diri seorang isteri sebagai sebahagian dari masyarakat adalah di antara punca yang mendorong mereka untuk hidup bermasyarakat dan cuba menimba pengalaman dengan melibatkan diri dengan alam pekerjaan dan sebagainya. Sebagai manusia, isteri tidak terlepas dari kehendaknya untuk melakukan sesuatu yang diingini. Kenyataan ini disokong dengan beberapa fakta sejarah, di mana kaum wanita atau isteri melibatkan diri dalam bidang pekerjaan dan urusan di luar rumah sama ada ia memerlukan kepakaran atau sebaliknya. Sebagai contoh, sebelum kedatangan Islam, Khadījah Khuwaylid terkenal dalam kalangan masyarakat Arab ketika itu sebagai bangsawan dan pedagang yang berjaya. Terdapat juga dalam kalangan mereka menceburkan diri dalam bidang perubatan seperti Zaynab dari kaum Bani 'Awwād. Beliau merupakan seorang doktor dalam bidang perubatan tubuh badan, mata dan kecederaan. Begitu juga, Rafidah al-Anșāriyyah yang sempat memeluk Islam dan bertugas sebagai jururawat yang merawat kecederaan yang dialami oleh penduduk Islam Madinah. ${ }^{2}$

Semenjak kedatangan Islam, ramai kalangan wanita atau isteri berketurunan Arab menceburkan diri dalam pelbagai bidang kehidupan manusia dan menjadi pesaing kepada kaum lelaki. Bahkan mereka hampir menyamai kaum lelaki dalam bidang yang diceburi samada dalam pembelajaran, pendidikan, politik dan pekerjaan. ${ }^{3}$ Ini memandangkan Islam bersikap adil dan sederhana serta tidak sesekali menghalang dan menyekat kebebasan wanita termasuk isteri terhadap urusan yang berkaitan dengan kehidupan dan keperluannya sebagai manusia walaupun ianya dilakukan di luar rumah dan berhadapan dengan masyarakat.

1 Yūsuf al-Qaraḍāwī (1996), Fatāwā li al-Mar'ah al-Muslimah, Irbid Jordan: Dār al-Furqān, h. 102.

2 Sa'īd 'Abd al-Fattāh 'Āsyūr (1994), Hadārah al-Islām, Kaherah: Fakulti Peradaban, Universiti al-Kaherah, c. 2, h. 205.

3 Kamīliyā Ibrāhīm 'Abd al-Fattāḥ (1984), Saikūlūjiyah al-Mar'ah al'Āmilah, Bayrut: Dār al-Nahụah al-'Arabiyyah, h. 54. 
ii-Firman Allah S.W.T. lagi yang bermaksud:

" Kedua wanita itu menjawab; " Kami tidak dapat meminumkan (ternak kami), sebelum pengembalapemngembala itu memulangkan (ternaknya), sedang bapak kami adalah orang tua yang telah lanjut umurnya'.

\section{Surah al-Qașaṣ (28):23}

Ayat di atas adalah bagi menguatkan lagi pandangan mereka yang berpendapat bahawa wanita atau isteri bekerja dan melibatkan diri dalam kerjaya di luar rumah diharuskan. Ini kerana, ayat di atas menjelaskan dua orang pemudi yang disebut dalam ayat di atas adalah untuk menyumbang dan membantu atau menolong ayah dan keluarganya yang tidak berupaya disebabkan tua dan sebagainya. Fenomena ini menggambarkan wanita atau isteri diharuskan keluar bekerja sekiranya memerlukan keperluan sebagaimana yang dijelaskan di atas.

iii-Kaedah Fiqh

Syariat Islam tidak membenarkan sesiapapun mengharamkan sesuatu perkara kecuali dia berpandukan kepada suatu nas dan dalil yang sah dari segi kesabitannya. ${ }^{4}$ Mengikut kaedah $f i q h^{5}$ :

"Asal suatu perkara adalah dihukumkan harus, sehingga ada dalil yang menunjukkan pengharamannya"

Kedua; Pandangan yang mengatakan wanita atau isteri tidak dibenarkan bekerja di luar rumah. Ini kerana tempat yang sesuai bagi kaum wanita adalah di rumah. Rumah adalah tempat untuk mereka menguruskan hal-ehwal rumah tangga dan mendidik anak-anak. Sekiranya mereka ikut serta bersama-sama kaum lelaki keluar melibatkan diri dalam pekerjaan, maka ia boleh

4 Al-Qaraḍāwī (1996), op. cit., h. 104; Muhammad Sālim al-'Awwā (1998), al-Fiqh al-Islāmī fi Tarīq al-Tajdìd, Beirut: al-Maktabah alIslāmī, c. 2, hh. 80-81.

5 Jalāl al-Dīn al-Suyūṭ̂̄ (1990), Asybāh wa al-Nazā 'ir, Beirut: Dār alKutub al-'Ilmiyyah, h. 60. 
menjejaskan hubungan kasih sayang dan pendidikan mereka terhadap anak-anak. ${ }^{6}$

Mereka yang tidak mengharuskan wanita atau isteri bekerja berpandukan kepada beberapa dalil daripada al-Quran yang dapat menguatkan pendapat mereka. Dalam mengemukakan dalildalil mereka, penulis juga mengutarakan beberapa kritikan dari majoriti ulama berhubung dalil-dalil tersebut. Di antara dalil yang dikemukakan oleh mereka yang tidak mengharuskan adalah sebagaimana berikut:

i- Firman Allah S.W.T. yang bermaksud:

"Dan hendaklah kamu menetap di rumahmu dan janganlah kamu berhias dan bertingkah laku seperti orang-orang jahiliyyah"

\section{Surah al-Aḩzāb (33): 33}

Ayat di atas menjelaskan bahawa Allah S.W.T. memerintahkan kaum wanita agar berada di rumah dan menegah dari menonjolkan perhiasan. Ini bermaksud wanita dilarang bercampur dengan kaum lelaki yang bukan mahramnya dalam satu tempat sama ada dalam situasi urusan jual beli, pekerjaan, musafir dan sebagainya. Justeru pekerjaan yang melibatkan wanita akan memberi kesan percampuran antara lelaki dan wanita sedangkan ia adalah perkara yang dilarang oleh Allah S.W.T. ${ }^{7}$

Namun menurut kebanyakan ulama tafsir menyatakan ayat di atas secara khususnya ditujukan kepada isteri-isteri Rasulullah S.A.W. Ini berdasarkan kepada ayat sebelum itu Allah S.W.T. menyatakan yang mana ertinya:

"Wahai isteri-isteri Nabi, sesiapa di antara kamu yang mengerjakan perbuatan keji yang nyata, nescaya akan digandakan seksaan kepada mereka dua kali lipat. Dan adalah yang demikian itu mudah bagi Allah".

6 Muhammad 'Uqlah (1990), Niz̄ām al-Usrah fì al-Islām, Amman Jordan: Maktabah al-Risālah al-Hadīthah, c. 2, h. 277.

$7 \quad$ Ibid, h. 278. 
Ayat di atas menjelaskan perintah agar wanita berada di rumah dan melarang mereka keluar rumah hanya dikhususkan kepada para isteri Rasulullah S.A.W. Ia tidak melibatkan kesemua wanita yang lain. ${ }^{8}$ Walaupun terdapat di kalangan ulama tafsir menjelaskan bahawa ayat 33 dalam surah al-Aḥzāb tidak dikhususkan kepada para isteri Rasulullah S.A.W. sahaja, bahkan ia meliputi wanitawanita selain mereka. Namun sekiranya mereka keluar disebabkan mempunyai keperluan dan hajat adalah dibenarkan tetapi perlu menjaga adab-adab sebagai wanita muslimah tanpa menyerupai perhiasan dan tingkah laku orang-orang jahiliyyah. ${ }^{9}$

ii- Firman Allah S.W.T. lagi yang bermaksud:

"Wahai Nabi, katakanlah kepada isteri-isterimu, anak-anak perempuanmu dan isteri-isteri orangorang yang beriman, "Hendaklah mereka mengulurkan jilbabnya keseluruh tubuh mereka”. Yang demikian itu supaya mereka lebih mudah untuk dikenal, kerana itu mereka tidak diganggu”.

Surah al-Aḥzāb (33): 59

Ayat di atas adalah suruhan Allah S.W.T. agar wanita melabuh jilbabnya ketika ke luar rumah agar mereka tidak diganggu oleh mereka yang mempunyai niat jahat terhadapnya. Justeru dengan penglibatan mereka dalam bidang pekerjaan akan mendedahkan kepada pergaulan mereka dengan kaum lelaki di samping menjejaskan sifat malu dan kewanitaannya apabila mereka dibiasakan dengan keadaan sedemikian. Dengan ini, mereka akan boleh terjebak ke dalam gejala yang tidak sihat sedangkan ianya dilarang oleh Allah. ${ }^{10}$

Namun dalam ayat ini tidak dinyatakan secara jelas berhubung dengan larangan wanita atau isteri keluar bekerja. Justeru tidak boleh dihukumkan haram wanita atau isteri keluar bekerja tanpa ada alasan dan nas nyata yang menghalang perbuatan demikian. ${ }^{11}$ Ini kerana, sekiranya wanita atau isteri tersebut dapat memelihara

\footnotetext{
8 Al-'Awwā (1998.), op.cit., h. 88.

9 Muḥammad Anwār al-Kasymīrī (1357), Fayd al-Bārī 'alā Șaḥīh alBukhārī, al-Majlis al-'Ilmi, India: Dabhil Surat, j. 1, h. 254.

10 'Uqlah (1990), op.cit., h. 278.

11 Al-Qaraḍāwī (1996), op.cit., h. 104.
} 
adab dan etika sebagaimana yang di sebut di atas, maka tidak menghalangnya untuk melibatkan diri dalam bidang pekerjaan.

iii- Firman Allah S.W.T. yang bermaksud:

\section{"Akan tetapi para suami mempunyai satu tingkatan kelebihan daripada isteri-isterinya".}

\section{Surah al-Baqarah (2); 228}

Ayat ini menjelaskan bahawa isteri mempunyai tahap dan kedudukan yang lebih rendah jika dibandingkan dengan kedudukan suami. Justeru isteri dilarang melibatkan diri dalam bidang pekerjaan sama ada memegang jawatan tinggi dalam kerajaan atau sebaliknya. Walau bagaimanapun, menurut Muhammad Sālim al'Awwā, ayat di atas tidak menyebutkan bahawa wanita atau isteri dilarang melibat diri dalam bidang pekerjaan sama ada menjawat jawatan tinggi dalam kerajaan ataupun tidak. Ini kerana ayat di atas hanya dikhususkan berkenaan dengan sistem kekeluargaan sahaja tidak melibatkan bidang-bidang yang lain. ${ }^{12}$

Berpandukan penjelasan di atas, jelaslah bahawa ayat-ayat yang dinyatakan oleh mereka yang melarang wanita atau isteri bekerja dan memegang jawatan tinggi dalam kerajaan tidak mempunyai dalil-dalil yang kukuh untuk mempertahankan pandangan mereka. Ini kerana wanita berhak mengecapi kebebasan dan keistimewaan sebagaimana yang terdapat pada kaum lelaki.

\section{ETIKA KERJA ISTERI}

Menurut Islam, kerja yang dilakukan oleh wanita atau isteri hendaklah memenuhi beberapa etika kerja sebagaimana yang telah ditetapkan oleh Syarak. Di antaranya sebagaimana berikut: ${ }^{13}$

i- Pekerjaan yang sesuai dengan tabiat, fitrah dan kemampuan wanita sama ada dari sudut pandangan syarak atau dari sudut jasmani atau kejiwaan mereka. Justeru, pekerjaan yang dibenarkan oleh Syarak ialah pekerjaan yang tidak mempunyai unsur-unsur haram. Sebagai contoh, kerja sebagai

12 Al-‘Awwā (1998.), op.cit., hh. 84-85.

13 Al-Qaraḍ̄āī (1996), op.cit., hh. 105-107; 'Uqlah (1990), op.cit., h. 286-291. 
pembantu kepada lelaki bujang atau setiausaha khas kepada pengarah atau seumpamanya yang lazimnya mereka akan berada berdua-duaan di dalam bilik atau sebagai penari yang boleh menimbulkan nafsu keinginan dan kelazatan dunia atau sebagai pelayan kelab malam yang semestinya menghidangkan minuman-minuman berbentuk arak dan memabukkan atau sebagai pramugari yang kebiasaannya menghidangkan kepada penumpang dengan minuman yang memabukkan dan dia bermusafir jauh tanpa mahram terutama ke negara-negara barat ataupun jenis pekerjaan-pekerjaan lain yang diharamkan oleh Islam sama ada ia dikhususkan untuk wanita atau ia meliputi lelaki dan wanita. Manakala pekerjaan yang sesuai dengan fitrah dan tabiat jasmani dan kejiwaan mereka adalah pekerjaan yang tidak melibatkan bebanan terhadap mereka, seperti pemandu bas, juruterbang, membina bangunan dan sebagainya. Ini kerana pekerjaan seumpama ini memerlukan kekuatan fizikal dan mental.

ii- Menjaga adab-adab sebagai wanita Islam apabila keluar bekerja sama ada dari sudut perhiasan, percakapan, tingkah laku dan sebagainya. ${ }^{14}$ Antara adabnya adalah menutup aurat, tidak memakai wangi-wangian yang membangkitkan berahi seseorang, tidak bergaul bebas atau berkhalwat dengan kaum lelaki, meminta keizinan dari suami dan sebagainya. Adabadab tersebut dijelaskan di dalam al-Quran, di antara firman Alalh S.W.T. yang bermaksud:

"Dan katakanlah kepada wanita yang beriman: "Hendaklah mereka menahan pandangannya dan memelihara kemaluannya dan janganlah mereka menampakkan perhiasannya kecuali yang (biasa) nampak daripadanya.

Surah al-Nūr (24): 31

Firman Allah S.W.T. lagi yang bermaksud:

"Dan janganlah mereka memukulkan kakinya agar diketahui perhiasan yang mereka sembunyi"

Surah al-Nūr (24): 31

14 Haya Mubarak al-Barik (2001), Ensiklopedia Wanita Muslimah, Khairul al-Husni, (terj), Kuala Lumpur: Pustaka Jiwa, c. 2, h. 223). 
FirmanNya lagi:

"Maka janganlah kamu tunduk dalam berbicara sehingga berkeinginanlah orang yang ada penyakit dalam hatinya (orang yang mempunyai niat berbuat serong dengan wanita seperti melakukan zina) dan ucapkanlah perkataan yang baik”

Surah al-Aḥzāb (33): 32

iii- Tidak mengkesampingkan kewajipan lain seperti kewajipan terhadap suami dan anak-anak. Ini kerana kewajipan terhadap keduanya lebih utama dari kerja mereka. Tambahan pula, di antara risiko yang berlaku apabila isteri bekerja adalah mengurang ruangkan dan masa mereka bersama suami dan anak-anak ${ }^{15}$ Justeru isteri hendaklah bijak membahagikan masa untuk menunaikan tanggungjawabnya bersama suami dan anak-anak agar kesejahteraan dan keharmonian rumahtangga dan keluarga dapat dikekalkan.

\section{NAFKAH ISTERI BEKERJA}

Nafkah merupakan hak isteri yang dipertanggunjawabkan ke atas suami, sama ada ia berbentuk wang ringgit, makanan, tempat tinggal dan sebagainya yang dianggap sebagai keperluan bagi seorang isteri. Pemberian nafkah seolah-olah sebagai pembalasan kepada isteri yang telah menjadi milik suami melalui akad yang sah. Isteri tidak lagi mempunyai kebebasan untuk keluar rumah dengan sewenang-wenangnya tanpa kebenaran suami kerana penahanan diri isteri yang sempurna (ihtibās kāmil) terhadap suami dan terikat melalui akad perkahwinan yang sah.

Realitihari inimemaparkan bahawawanita-wanitayangbergelar isteri kebanyakannya berkecimpung dalam dunia pekerjaan. Lebih-lebih lagi mereka yang mempunyai kelayakan dalam bidang profesional seperti kedoktoran, kejuruteraan, kehakiman dan sebagainya. Sehubungan itu, Islam mengharuskan wanita keluar bekerja berpandukan pandangan ulama yang menegaskan bahwa harus bagi wanita yang tidak mempunyai sumber pendapatan

15 Kamīliyā Ibrāhīm (1984), op.cit., hh. 94 dan 96. 
sama ada dari pihak suami, kaum kerabatnya atau pun Baitulmal mencari pekerjaan untuk menyara kehidupan. ${ }^{16}$

Dengan ini, isteri yang bekerja di luar rumah meyebabkan penyerahan dirinya terhadap suami terjejas. Sedangkan penyerahan diri isteri yang sempurna terhadap suami adalah syarat bagi isteri mendapat hak nafkah dari suami. Justeru adakah penyerahan diri isteri yang tidak sempurna (ihtibās nāqiș) kepada suami menyebabkan suami masih diwajibkan menanggung nafkah isteri ataupun tidak. Adakah hak tersebut gugur sekiranya isteri keluar bekerja tanpa keizinan suami kerana perbuatan tersebut dianggap sebagai perbuatan nusyuz. Justeru penentuan hukum diperlukan bagi menjawab segala persoalan yang timbul di atas.

Mereka bersepakat menyatakan sekiranya pendapat suami sudah mencukupi untuk membiayai perbelanjaan keluarga dan dia tidak membenarkan isteri keluar bekerja, maka haram kepada isteri mengingkari larangan tersebut dan dia berhak mendapat nafkah dari suaminya. Ini kerana di antara hak suami yang sewajarnya menjadi tanggungjawab isteri ialah mentaati suami dan penyerahan sempurna untuk suami sama ada di waktu siang atau malam. Justeru penglibatan isteri dalam bidang kerjaya dan pekerjaan di luar rumah akan menjejaskan ruang dan masanya yang sepatutnya diperuntukkan bersama suami terutama pekerjaan yang boleh memberi kesan sampingan terhadap kesihatan dan keterampilannya. ${ }^{17}$

Begitu juga keadaannya, sekira isteri dibenarkan keluar bekerja di peringkat permulaan kemudian suaminya tidak mengizinkan selepas daripada itu dan isteri enggan menurut perintah suami. Keengganan isteri menurut kehendak suami dianggap sebagai derhaka (nusyuz) yang menghalang isteri mendapat nafkah dari suami. Dalam situasi lain pula, sekiranya isteri dibenarkan oleh suami untuk melibatkan diri dalam bidang pekerjaan dan kerjaya dalam tempoh masa yang agak lama selepas berkahwin, menurut sebahagian ulama suami masih berhak meminta agar isteri berhenti dari melibatkan diri dalam bidang pekerjaan. Namun sebahagian

16 Ibn 'Ābidīn, Muḥammad Amīn b. 'Umar b. 'Abd al-'Azīz (t.t), alDurr al-Mukhtār, Beirut: Dār al-Fikr, j.2, h. 671.

17 'Abd al-Fattāh 'Amr (1998), al-Siyāsah al-Syar'iyyah fi al-Ahwāl al-Syakhșiyyah, Jordan: Dār al-Nafâ' is, h. 88. 
lain pula berpendapat, suami tidak berhak lagi menghalang isterinya dan isteri berhak mendapat nafkah dari suami walaupun penyerahan isteri terhadap suami berkurangan. ${ }^{18}$

Sementara itu, suami tidak boleh menghalang isteri dari melibatkan diri dalam bidang pekerjaan yang dilakukan di dalam rumah seperti menjahit atau menenun pakaian dan sebagainya. Namun suami berhak menghalang sekiranya pekerjaan tersebut boleh mendatangkan kemudharatan dan menjejaskan keterampilan isteri. Akan tetapi isteri tidak dianggap derhaka dan ia tetap berhak mendapat nafkah sekiranya ia masih meneruskan pekerjaan tersebut. Ini kerana isteri tidak mengurangkan penyerahannya kepada suami kerana pekerjaan tersebut dilakukan di dalam rumah. Dalam situasi ini suami berhak memberi tunjuk ajar ( ta $\left.^{\prime} \mathrm{dib}\right)$ terhadap isteri disebabkan keengganannya. ${ }^{19}$

Namun menurut Abu Hanifah, sekiranya isteri mensyaratkan ketika melakukan akad perkahwinan agar mengekalkan penglibatannya dalam pekerjaan yang melibatkan di luar rumah walaupun setelah perkahwinan, maka ia tidak sah dan hendaklah dihapuskan syarat tersebut dan akad tidak terbatal dengan syarat demikian. Justeru suami berhak menegah isteri dari melibatkan diri dalam bidang pekerjaan dan sekiranya isteri berdegil juga, maka dia dianggap telah melakukan penderhakaan (nusyuz) terhadap suami dan dia tidak berhak mendapat nafkah.

Manakala menurut al-Mālikiyyah, syarat di atas dianggap sah tetapi makruh melakukannya kerana ia dapat memberi kesan sampingan terhadap suami dalam pergaulan sesama mereka. Sebagaimana juga sekiranya isteri mensyaratkan agar suaminya tidak boleh berkahwin dengannya atau dia tidak mahu berpindah dari rumah ayahnya atau negerinya, maka tidak perlu ditunaikan

18 Badrān Abū 'Ainain Badrān (t.t.), al-Fiqh al-Muqāran li al-Aḥwāl al-Syakhșiyyah baina al-Madhāhib al-Arba'ah al-Sunniyyah wa alMadhhab al-Ja farī wa al-Qānūn, j. 1, Beirut: Dār al-Nahḍah al'Arabiyyah, hh. 241-242; 'Abd al-Majīd Mạ̣mūd Mațlūb (1995), al-Wajüz fi Aḥkām al-Usrah al-Islāmiyyah, Giza Mesir: Ma'had alDirāsat al-Islāmiyyah, hh. 172-173; Zakī al-Dīn Sya'bān (1989), alAhkām al-Syar'iyyah li al-Aḥwāl al-Syakhșiyyah, Jāmi‘ah Qar Yūnus, h. 319.

Ibid., h. 321; Badran, op. cit., h. 242. 
syarat tersebut. Justeru suami berhak menghalang isteri dari melibatkan diri dalam bidang pekerjaan dan jika isteri tidak mematuhi arahan tersebut, maka dia telah melakukan nusyuz terhadap suaminya dan suami tidak berhak memberi nafkah kepadanya.

Sementara itu, menurut al-Hanābilah syarat dikemukakan oleh isteri dianggap sah. Suami tidak berhak menghalang isteri dari meneruskan pekerjaannya dan ia tidak dianggap derhaka (nusyuz) terhadap suaminya sekiranya dia tidak mematuhi halangan tersebut, bahkan dia berhak mendapat nafkah. Walau bagaimanapun, pekerjaan yang diceburi oleh isteri hendaklah memenuhi kehendak kemaslahatan keluarga. Sekiranya tidak memenuhi kehendak tersebut, suami berhak menghalang isteri. ${ }^{20}$

Dari penjelasan beberapa pandangan para sarjana Islam berhubung dengan permasalahan di atas, dapat dibuat rumusan bahawa mereka berpendapat suami mempunyai kuasa dan kedudukan sebagai suami boleh menggunakan haknya yang mesti dipertanggungjawabkan oleh isteri, di antaranya isteri hendaklah mentaati suami dalam semua keadaan termasuk dalam isu isteri yang ingin melibatkan diri dalam bidang pekerjaan. Justeru isteri dianggap nusyuz sekiranya dia tidak mematuhi arahan suami agar tidak melibatkan diri dalam bidang tersebut. Selain itu, isteri tidak berhak mendapat nafkah dari suami rentetan keengganannya menurut perintah suami.

Namun sebahagian sarjana perundangan kontemporeri seperti 'Abd al-Fattāh 'Amr ${ }^{21}$ dan lain-lain berpendapat isu yang diutarakan adalah berbeza dengan pandangan yang dikemukakan oleh majoriti sarjana perundangan Islam. Ini kerana, isu berkenaan nafkah isteri bekerja berubah disebabkan perbezaan masa. Sebagai contoh, masyarakat memerlukan penglibatan wanita dalam bidang yang hanya melibatkan kaum wanita seperti tenaga pengajar anak-anak perempuan, pegawai perubatan kepada pesakit-pesakit wanita dan sebagainya sebagai alternatif tugas-tugas kaum lelaki. Menurut mereka suami tidak berhak menentukan bahawa bakal isteri hendaklah terlebih dahulu mendapat keizinan daripadanya

20 Zakiy al-Din Sha'ban, op. cit., h. 320-321.

21 'Abd al-Fattah 'Amr(Dr.)(1418H/1998M), al-Siyasahal-Shar'iyyah fi al-Ahwal al-Shakhsiyyah, Jordan: Dar al-Nafais, h. 93. 
sebelum melakukan akad perkahwinan untuk melibatkan diri dalam bidang perkerjaan. Begitu juga keadaannya selepas melakukan akad perkahwinan sama ada bersebab atau tidak, isteri tidak dianggap melakukan nusyuz yang menghalangnya mendapat nafkah dari suaminya sekiranya dia masih tetap melibatkan diri dalam bidang pekerjaan sekalipun dilarang oleh suaminya.

Namun pekerjaan tersebut mestilah memenuhi beberapa syarat seperti pekerjaan yang memenuhi kepentingan asasi (darūr $\bar{\imath}$ ) dan keperluan yang mendesak (hājat mulahhah). Ini kerana tidak ada nas secara jelas yang menunjukkan isteri berhak atau tidak berhak mendapat nafkah disebabkan melibatkan diri dalam bidang pekerjaan. Di samping itu, ulama menjelaskan bahawa nas hanya menganggap nusyuz isteri terhadap suami berlaku disebabkan situasi dan suasana pekerjaan isteri di luar rumah tidak bersifat untuk memenuhi kepentingan asasi dan keperluan yang mendesak. Tambahan pula, nafkah yang diberikan oleh suami kepadanya sudah memadai untuk menyara kehidupan dan dia tidak memerlukan harta yang lain. Kenyataan tersebut selari dengan apa yang diutarakan oleh sarjana perundangan Islam yang menyatakan bahawa isteri tidak berhak mendapat nafkah sekiranya pekerjaan tersebut tidak bersifat memenuhi kepentingan asasi dan keperluan mendesak.

\section{FAKTOR PEMILIHAN LOKASI KAJIAN}

Pemilihan Daerah Pasir Mas Kelantan sebagai lokasi kajian adalah sesuai kerana ia menepati beberapa ciri yang perlu dalam kajian ini. Antara faktor ialah kajian berkenaan kedudukan nafkah isteri bekerja di lokasi ini belum dilakukan. Di samping itu lokasi tersebut berada berhampiran dengan tempat kediaman keluarga penulis yang memungkinkan penulis membuat kajian ini dengan lebih mudah dan berkesan.

Pemilihan lokasi ini terutama bandar Pasir Mas adalah antara lain disebabkan ia merupakan di antara kawasan yang paling pesat membangun dan menjadi tumpuan utama bagi penduduk Jajahan Pasir Mas. Ini kerana ia merupakan pusat pelbagai kegiatan ekonomi iaitu melibatkan perniagaan, kakitangan awam dan swasta serta kegiatan-kegiatan ekonomi lain. Selain itu terdapat 
pejabat-pejabat kerajaan, swasta dan perkhidmatan awam (Pejabat Penggawa Daerah Pasir Mas; Bahagian Pembangunan, t.t).

Faktor seterusnya ialah kerana kesesuaian lokasinya yang mewakili majoriti Melayu yang beragama Islam serta penduduknya kebanyakan terdiri daripada kaum perempuan. Memandangkan lokasi ini kawasan tumpuan kegiatan ekonomi, ini dapat mempengaruhi kaum perempuan termasuk mereka yang sudah bergelar isteri meceburkankan diri dalam bidang pekerjaan. Antara faktornya juga lokasi ini berada di kawasan yang terdapat beberapa buah Pusat Pengajian Pondok seperti Pondok Pak Su Wil di Kampung Dangar dan Pondok Haji Abdullah di hadapan Pusat Kesihatan Besar Pasir Mas (Pejabat Penggawa Daerah Pasir Mas). Ini dapat memberi gambaran mengenai pengaruh dan tahap kefahaman serta pengamalan masyarakat Islam yang telah mendirikan rumahtangga terhadap tanggungjawab mereka sabagai suami isteri, terutama yang melibatkan kewajipan nafkah.

\section{LAPORAN PENYELIDIKAN DAN ANALISIS DATA}

Dalam bahagian ini penulis mengklasifikasikan kepada dua katogeri, iaitu laporan penyelidikan dan penganalisisan data berkenaan latarbelakang isteri bekerja di Daerah Pasir Mas Kelantan dan kedudukan nafkahnya.

\section{Latar belakang Responden}

Penulis telahmengedarkan borangkajiselidikkepada200 responden namun hanya 150 reseponden sahaja yang dapat memulangkan borang kaji selidik dan ia boleh dijadikan sebagai sampel terhadap kajian ini. Borang tersebut diedar kepada isteri bekerja di Daerah Pasir Mas Kelantan yang terdiri daripada pelbagai sektor, di antaranya sektor kerajaan dan sektor swasta serta yang bekerja sendiri seperti menjahit, berniaga dan sebagainya. Kajian ini juga merangkumi responden yang tinggal bersama suami ataupun tidak. Ia juga akan mengetengahkan dari sudut umur, taraf pendidikan responden, kedudukan pekerjaan dan pendapatan responden dan suami, faktor-faktor mendorong responden bekerja, tindak balas suami terhadap pekerjaan responden 


\section{i. Umur Dan Taraf Pendidikan Responden}

Daripada jumlah 150 responden, kajian mendapati tahap umur responden berbeza-beza di antara satu sama lain. Kebanyakan responden berumur dalam lingkungan 36 hingga 45 tahun iaitu seramai 78 responden, ini diikuti oleh 42 responden berusia di antara 26 hingga 35, seterusnya 24 responden berumur 46 ke atas dan disusuli pula 6 responden berusia dalam lingkungan 15 hingga 25. Hal ini menggambarkan terdapat sebahagian kecil wanita di Pasir Mas yang telah berkahwin seawal umur 15 tahun dan telah menceburkan diri dalam bidang perniagaan. Ini dapat dilihat dengan lebih jelas dalam jadual 1 .

Jadual 1: Umur Responden

\begin{tabular}{ccc}
\hline Umur & Kekerapan & \% \\
\hline $15-25$ & 6 & 4 \\
$26-35$ & 42 & 28 \\
$36-45$ & 78 & 52 \\
46 ke atas & 24 & 16 \\
Jumlah & $\mathbf{1 5 0}$ & $\mathbf{1 0 0}$ \\
\hline
\end{tabular}

Sumber: Borang Kaji Selidik

Responden terdiri daripada mereka yang mempunyai taraf pendidikan yang berbeza. Kebanyakan mereka ialah lepasan SPM iaitu seramai 57 orang (38\%), ini diikuti olej 54 responden $(36 \%)$ yang mempunyai kelulusan ijazah, 27 orang (18\%) lepasan STP dan masing-masing 6 orang (4\%) lepasan PMR dan lain-lain kelulusan. Laporan ini dapat dilihat dalam jadual 2.

Jadual 2: Taraf Pendidikan Responden

\begin{tabular}{ccc}
\hline Taraf Pendidikan & Kekerapan & $\mathbf{\%}$ \\
\hline PMR & 6 & 4 \\
SPM & 57 & 38 \\
STPM & 27 & 18 \\
Ijazah & 54 & 36 \\
Lain-lain & 6 & 4 \\
Jumlah & $\mathbf{1 5 0}$ & $\mathbf{1 0 0}$ \\
\hline
\end{tabular}

Sumber: Borang Kaji Selidik 


\section{ii. Kedudukan Pekerjaan Responden Dan Suami}

Penulis mendapati pekerjaan yang disandang oleh seseorang amat penting untuk menentukan kestabilan ekonomi sesebuah rumahtangga. Kestabilan ekonomi berpunca daripada sumber pendapatan yang kukuh dan lumayan. Di samping itu, ia boleh membezakan kedudukan ekonomi rumahtangga masing-masing. Hasil kajian mendapati majoriti responden dan suami berminat bekerja dengan kerajaan berbanding swasta dan bekerja. Ini kerana seramai 130 responden (87\%) adalah kakitangan kerajaan, diikuti seramai 15 orang $(10 \%)$ adalah kakitangan swasta dan seramai 5 orang $(3 \%)$ bekerja sendiri. Kenyataan ini dapat dilihat dengan lebih jelas di dalam jadual 4.3 dan carta 4.3. Sementara kedudukan pekerjaan suami responden masing-masing, seramai 97 orang (64\%) adalah kakitangan kerajaan, dikuti seramai 25 orang (17 $\%)$ terdiri daripada kakitangan swasta, seramai 22 orang (15\%) bekerja sendiri dan 6 orang (4\%) adalah pesara. Kedudukan ini dapat dilihat dalam jadual 3 dan 4 .

Jadual 3: Pekerjaan Responden

\begin{tabular}{ccc}
\hline $\begin{array}{c}\text { Pekerjaan } \\
\text { Responden }\end{array}$ & Kekerapan & \% \\
\hline $\begin{array}{c}\text { Kakitangan } \\
\text { Kerajaan }\end{array}$ & 130 & 87 \\
Kakitangan & 15 & 10 \\
Swasta & 5 & 3 \\
Sendiri & $\mathbf{1 5 0}$ & $\mathbf{1 0 0}$ \\
\hline Jumlah &
\end{tabular}

Sumber: Borang Kaji Selidik

Jadual 4: Pekerjaan Suami Responden

\begin{tabular}{ccc}
\hline $\begin{array}{c}\text { Pekerjaan Suami } \\
\text { Responden }\end{array}$ & Kekerapan & \% \\
\hline Kakitangan Kerajaan & 97 & 64 \\
Kakitangan Swasta & 25 & 17 \\
Sendiri & 22 & 15 \\
Bersara & 6 & 4 \\
Jumlah & $\mathbf{1 5 0}$ & $\mathbf{1 0 0}$ \\
\hline
\end{tabular}

Sumber: Borang Kaji Selidik 
Berdasarkan jadual di atas juga, dapat digambarkan bahawa responden mempunyai sikap tolong-menolong dalam meningkatkan taraf hidup keluarga meskipun terdapat sebahagian daripada suami mereka telah mempunyai pekerjaan. Kemungkinan ia disebabkan desakan taraf hidup yang semakin tinggi dan mempunyai komitmen yang banyak.

Dari hasil penyelidikan juga didapati pendapatan bulanan responden dan suami tiada jurang perbezaan yang begitu ketara. Seramai 15 responden dan 12 orang suami menerima pendapatan bulanan antara RM500 ke bawah, diikuti 27 responden dan 36 orang suami menerima antara RM501 hingga RM1000, ini disusuli pula seramai 72 responden dan 60 orang suami menerima RM1001 hingga RM2000 dan seramai 36 responden dan 42 orang suami menerima RM2001 ke atas. Ini dapat dilihat dengan lebih jelas dalam jadual 5 .

Jadual 5: Pendapatan Bulanan Responden Dan Suami

\begin{tabular}{ccc}
\hline $\begin{array}{c}\text { Pendapatan Bulanan } \\
\text { (RM) }\end{array}$ & Responden & Suami \\
\hline RM 500 ke bawah & 15 & 12 \\
RM 501 - RM1000 & 27 & 36 \\
RM1001 - RM2001 & 72 & 60 \\
RM 2001 ke atas & 36 & 42 \\
Jumlah & $\mathbf{1 5 0}$ & $\mathbf{1 5 0}$ \\
\hline
\end{tabular}

Sumber: Borang Kaji Selidik

\section{iii. Faktor-Faktor Mendorong Responden Bekerja}

Walaupun pada asasnya tugas mencari nafkah adalah diwajibkan ke atas suami tetapi disebabkan keadaan-keadaan tertentu isteri sewajarnya turut serta bekerja di luar rumah. Berpandukan kajian yang dilakukan, dapatan kajian menunjukkan bahawa faktor menambahkan pendapatan suami merupakan pendorong utama kepada responden keluar bekerja dengan jumlah paling tinggi iaitu 95 responden, ini diikuti oleh faktor mempunyai kelulusan tinggi 24 orang, menanggung ibubapa seramai 22 responden, dan faktor mencari kebebasan 9 orang. Ini dapat dilihat dengan lebih jelas di dalam jadual 6 . 
Jadual 6: Faktor-Faktor Mendorong Responden Bekerja

\begin{tabular}{lcc}
\hline $\begin{array}{l}\text { Faktor-Faktor Mendorong } \\
\text { Responden Bekerja }\end{array}$ & Kekerapan & $\mathbf{\%}$ \\
\hline Menambah Pendapatan Suami & 95 & 63 \\
Menanggung Ibubapa dan Adik & 22 & 15 \\
Beradik & 24 & 16 \\
Mempunyai Kelulusan Tinggi & 9 & 6 \\
Mencari Kebebasan & $\mathbf{1 5 0}$ & $\mathbf{1 0 0}$ \\
\hline
\end{tabular}

Sumber: Borang Kaji Selidik

iv. Anggaran Perbelanjaan Bulanan Rumahtangga

Menurut pengamatan penulis, pekerjaan dan pendapatan serta sikap toleransi responden memainkan peranan yang penting dalam menyempurnakan anggaran perbelanjaan bulanan rumahtangga. Ini memandangkan, hasil kajian mendapati bahawa anggaran perbelanjaan rumahtangga sejumlah RM1001 ke atas adalah anggaran yang paling ramai responden terlibat iaitu 81 orang, diikuti, 48 responden yang menganggarkan perbelanjaan bulanan rumahtangga antara RM501 hingga RM1000. Manakala 21 responden sahaja yang menganggarkannya sebanyak antara RM100 hingga RM501. Ini dapat dilihat dengan lebih jelas dalam jadual 7 di bawah.

Jadual 7: Anggaran Perbelanjaan Bulanan Rumah Tangga

\begin{tabular}{ccc}
\hline $\begin{array}{c}\text { Anggaran Perbelanjaan } \\
\text { Bulanan }\end{array}$ & Kekerapan & $\mathbf{\%}$ \\
\hline RM100 - RM500 & 21 & 14 \\
RM501 - RM1000 & 48 & 32 \\
RM1001 ke atas & 81 & 54 \\
Jumlah & $\mathbf{1 5 0}$ & $\mathbf{1 0 0}$ \\
\hline
\end{tabular}

Sumber: Borang Kaji Selidik

\section{Kedudukan Nafkah Responden}

Proses menganalisa kedudukan nafkah di kalangan isteri bekerja melibatkan beberapa perkara iaitu berkenaan dengan penerimaan nafkah responden daripada suami sama ada ia dijadikan rutin 
bulanan atau tidak, kadar penerimaan nafkah, bentuk nafkah yang diperolehi oleh isteri, cara penerimaan nafkah, kadar penggunaan pendapatan responden digunakan tujuan perbelanjaan rumahtangga, kebebasan responden menggunakan pendapatan mereka dan juga cara pengagihan pendapatan responden untuk kegunaan lain-lain.

\section{i. Penerimaan Nafkah Responden Daripada Suami}

Berdasarkankajiandanpenganalisaan penulis mendapatipemberian nafkah oleh suami terhadap responden berdasarkan kepada tiga situasi iaitu $84 \%$ daripada responden menerima daripada suami, manakala $8 \%$ tidak menerima nafkah di sebabkan beberapa faktor di antaranya suami tidak mampu dan tidak mempunyai pekerjaan. Sementara $8 \%$ daripada mereka pula tidak menjadikan pemberian nafkah sebagai rutin bulanan di dalam kehidupan rumahtangga mereka kerana mengikut keperluan semasa. Situasi tersebut dapat dilihat dengan lebih jelas berpandukan kepada Jadual 8 berikut:

Jadual 8: Penerimaan Nafkah Responden Daripada Suami

\begin{tabular}{ccc}
\hline Penerimaan Nafkah & Kekerapan & $\mathbf{\%}$ \\
\hline Ya & 126 & 84 \\
Tidak & 12 & 8 \\
Bukan Rutin Bulanan & 12 & 8 \\
Jumlah & $\mathbf{1 5 0}$ & $\mathbf{1 0 0}$ \\
\hline
\end{tabular}

Sumber: Borang Kaji Selidik

\section{ii. Kadar Penerimaan Nafkah}

Hasil soal selidik terhadap 150 responden menunjukkan kadar penerimaan nafkah yang berbentuk wang ringgit di kalangan responden agak berbeza-beza mengikut status pekerjaan yang disandang oleh suami. Majoriti responden (27\%) menerima nafkah RM501 ke atas. Minoriti mereka (3\%) pula menerima RM50-RM100, ini diikuti 25\% menerima RM101-RM300, 24\% menerima RM301-RM500 dan 13\% menerima mengikut keperluan. Namun $8 \%$ responden tidak menerima nafkah. Kadar penerimaan tersebut boleh dilihat secara lebih jelas dalam Jadual 9 berikut. 
Jadual 9: Kadar Penerimaan Nafkah

\begin{tabular}{ccc}
\hline Kadar Penerimaan Nafkah (RM) & Kekerapan & $\mathbf{\%}$ \\
\hline RM50 - RM100 & 4 & 3 \\
RM101 - RM300 & 37 & 25 \\
RM301 - RM500 & 36 & 24 \\
RM501 - ke atas & 41 & 27 \\
Mengikut Keperluan & 20 & 13 \\
Tidak Menerima Nafkah & 12 & 8 \\
Jumlah & $\mathbf{1 5 0}$ & $\mathbf{1 0 0}$ \\
\hline
\end{tabular}

Sumber: Borang Kaji Selidik

\section{iii. Bentuk Nafkah Selain Wang Ringgit}

Berkenaan bentuk nafkah selain wang ringgit, penulis telah memberi pilihan kepada responden untuk menjawab lebih dari satu jawapan. Berdasarkan kepada penganalisaan terhadap kajian tersebut menunjukkan bentuk nafkah yang berupa kediaman amat dititik beratkan oleh responden berdasarkan 139 daripada 150 orang responden memilih nafkah tersebut melalui kaji selidik penulis. Diikuti pula oleh nafkah makanan seramai 134 responden, nafkah pakaian seramai 128 responden dan kenderaan 107 responden.

\section{iv. Cara Penerimaan Nafkah}

Kajian ini berdasarkan kepada 138 responden yang menerima nafkah dari suami termasuk 6 responden yang tinggal berasingan dengan suami mereka dan 12 responden menerima nafkah ketika perlu sahaja. Namun kajian ini tidak termasuk 12 responden yang tidak mendapat nafkah daripada suami mereka. Bagi responden yang tinggal berasingan dengan suami mereka, cara penerimaannya ia dibawa pulang sendiri oleh suami responden. Dari jumlah tersebut $67 \%$ daripada responden menerima nafkah setiap bulan, diikuti $15 \%$ menerimanya setiap minggu, $9 \%$ menerimanya setiap hari dan 9\% pula menerimanya mengikut keperluan. Cara-cara tersebut dapat dilihat malalui Jadual 10. 
Jadual 10: Cara Penerimaan Nafkah

\begin{tabular}{lcc}
\hline Cara Penerimaan Nafkah & Kekerapan & $\mathbf{\%}$ \\
\hline Setiap hari & 13 & 9 \\
Setiap Minggu & 21 & 15 \\
Setiap Bulan & 92 & 67 \\
Mengikut Keperluan & 12 & 9 \\
Jumlah & $\mathbf{1 5 0}$ & $\mathbf{1 0 0}$ \\
\hline
\end{tabular}

Sumber: Borang Kaji Selidik

v. Kebebasan Menggunakan Pendapatan

Penulis mendapati majoriti responden mempunyai kebebasan untuk menggunakan pendapatan bulanan mereka. Namun masih ada sebilangan kecil (5\%) dari mereka yang tidak diberi kebebasan oleh suami untuk menggunakan pendapatan mereka bagi tujuan peribadi. Ini kerana mereka perlu berbincang terlebih dahulu dengan suami untuk perbelanjaan bersama. Status kebebasan responden menggunakan pendapatan bulanan mereka dapat dilihat dalam jadual 11.

Jadual 11: Kebebasan Responden Menggunakan Pendapatan Bulanan Mereka

\begin{tabular}{lcc}
\hline Kebebesan Menggunakan Pendapatan & Kekerapan & $\mathbf{\%}$ \\
\hline Bebas & 143 & 95 \\
Tidak Bebas & 7 & 5 \\
Jumlah & $\mathbf{1 5 0}$ & $\mathbf{1 0 0}$ \\
\hline
\end{tabular}

Sumber: Borang Kaji Selidik

vi. Pendapatan Responden Untuk Perbelanjaan Rumahtangga

Kajian menunjukkan isteri turut serta memainkan peranan penting dalam mengeluarkan pendapatan bulanan mereka untuk perbelanjaan rumahtangga walaupun mereka diberi kebebasan menguruskan pendapatan tersebut. Ini menunjukkan bahawa mereka mempunyai sifat toleransi dan sikap kerjasama dalam kehidupan rumahtangga serta memahami situasi atau nilai semasa dan setempat serta taraf kehidupan masakini. Namun ia berubah mengikut keperluan dan kehendak perbelanjaan rumahtangga masing-masing. Justeru kajian mendapati seramai 126 responden mengeluarkan pendapatan bulanan mereka untuk perbelanjaan rumahtangga. Sementara 24 daripada mereka tidak mengeluarkan 
pendapatan bulanan untuk tujuan tersebut. Ini dapat dilihat pada jadual 12.

Jadual 12: Pendapatan Bulanan Responden Untuk Perbelanjaan Rumah Tangga

\begin{tabular}{lcc}
\hline $\begin{array}{l}\text { Pendapatan Responden Untuk } \\
\text { Perbelanjaan Rumahtangga }\end{array}$ & Kekerapan & \% \\
\hline Ya & 126 & 84 \\
Tidak & 24 & 16 \\
Jumlah & $\mathbf{1 5 0}$ & $\mathbf{1 0 0}$ \\
\hline
\end{tabular}

Sumber: Borang Kaji Selidik

Sikap tolerasi mereka juga dapat dilihat dengan begitu jelas melalui kadar pengeluaran pendapatan bulanan responden dalam kajian ini. Penulis mendapati seramai 51 responden mengeluarkan separa pendapatan bulanan mereka bagi tujuan tersebut dan 49 responden mengeluarkan lebih daripada separa. Ini diikuti pula 26 responden mengeluarkan pendapatan bulanan mereka mengikut keperluan perbelajaan tanpa mengehadkan pengeluaran tersebut. Kenyataan di atas dapat dilihat dalam jadual 13.

Jadual13: Kadar Perbelanjaan Pendapatan Bulanan Responden Untuk Rumah Tangga

\begin{tabular}{lc}
\hline Kadar Perbelanjaan Pendapatan Responden & Bilangan \\
Untuk Rumahtangga & 51 \\
\hline Separa & 49 \\
Lebih daripada separa & 26 \\
Mengikut keperluan & $\mathbf{1 2 6}$ \\
\hline Jumlah & \\
\hline
\end{tabular}

Sumber: Borang Kaji Selidik

vii. Cara Pengagihan Pendapatan Bulanan

Menurut kajian penulis, responden mempunyai cara masingmasing dalam mengagihkan pendapatan bulanan mereka. Di samping mereka menyalurkan pendapatan tersebut bagi tujuan perbelanjaan rumahtangga, mereka juga mengagihkan pendapatan mereka bagi tujuan lain. Dalam soal selidik, responden diberi pilihan untuk menjawab lebih daripada satu. Penulis dapati cara pengagihan mereka lebih cenderung dalam bentuk simpanan 
berbanding dengan bentuk-bentuk lain. Seramai 139 orang memilih untuk menyimpan, diikuti 115 orang mengagihkannya untuk membeli pakaian, 113 orang pula memilih untuk membantu ibubapa dan 90 orang pula membelanjakan bagi tujuan membeli peralatan rumah. Ini dapat dilihat dalam jadual 14.

Jadual 14: Cara Pengagihan Pendapatan Bulanan Responden Selain Perbelanjaan Rumah Tangga

\section{Cara Pengagihan Pendapatan Bulanan Responden}

Membantu ibubapa

Peralatan rumah

Simpanan

Membeli pakaian

Sumber: Borang Kaji Selidik

\section{Bilangan}

115

\section{HASIL KAJIAN}

Dapatankajian menunjukkan majoriti suami responden mempunyai tahap kefahaman dan pengalaman yang baik terhadap nafkah isteri bekerja di Daerah Pasir Mas dan ia menepati dengan kehendak syarak. Ini dapat dilihat kebanyakan responden menerima nafkah mereka daripada suami walaupun berbeza dari sudut kadar dan cara penerimaan nafkah. Namun masih terdapat sebilangan kecil suami responden yang tidak memenuhi tanggungjawab tersebut disebabkan ketidakmampuan suami memberi nafkah kepada responden sama ada mereka mempunyai pendapatan yang rendah, sakit atau tiada pekerjaan. Walau bagaimanapun, sebilangan kecil responden menerima hakikat keadaan suaminya yang tidak berkemampuan.

Kajian juga mendapati selain wang ringgit, suami responden juga tidak mengabaikan beberapa bentuk nafkah yang lain. Di antara bentuk nafkah selain wang ringgit yang dititik beratkan oleh suami responden ialah kediaman, pakaian, makanan dan kenderaan. Ini kerana keempat-empat bentuk nafkah tersebut amat diperlukan dalam kehidupan.

Di samping itu, kajian menunjukkan majoriti responden turut memainkan peranan yang sewajarnya dalam usaha merealisasikan 
konsep kerjasama dan toleransi dalam kehidupan rumahtangga serta memahami nilai semasa dan setempat walaupun mereka diberi kebebasan membelanjakan pendapatan bulanan mereka. Ini dapat dilihat melalui sejumlah pendapatan bulanan mereka digunakan untuk perbelanjaan bulanan rumahtangga mereka.

\section{KESIMPULAN}

Antara fenomena yang berlaku terhadap sebahagian masyarakat Islam di Pasir Mas ialah isteri turut sama keluarbekerja sebagaimana suami. Walaupun isteri bekerja dan mempunyai pendapatan sendiri, namun kebanyakan suami mempunyai kefahaman tentang tanggungjawabnya sebagai suami kerana mereka masih memberi nafkah kepada isterinya berdasarkan kepada kemampuan atau pendapatan suami. Dalam pada itu, kebanyakan suami dilihat berfikiran positif dalam membina rumah tangga bahagia apabila melepaskan tangan atau mengabaikan tanggungjawab meskipun isteri mereka sudah mampu menyara dirinya sendiri. Tambahan pula kehidupan mereka jelas menampakkan sikap bekerjasama, saling bantu membantu dan faham memahami antara satu sama lain bagi mempastikan rumah tangga yang di bina sentiasa dirahmati dan diberkati Allah. Apabila wujudnya bersefahaman dan persepakatan, maka sudah tentu tidak timbul masalah menuntut ganti rugi dan sebagainya. 